\title{
The Study on Combustion Chamber Deposit (Part 5) The Role of Combustion Chamber Deposits in Fuel Economy
}

\author{
Yoshiaki Yonekawa*, Kakuro Kokubo*, Yoshinobu Nakamura* \\ and Nobukazu Окамото*
}

\begin{abstract}
The present study concerns primarily with combustion analyses under deposited conditions in engine combustion chamber and with the effect of engine deposits on fuel economy using a mini-engine.

The engine deposits in the mini-engine were found to afford a beneficial effect on fuel saving. Energy distributions with and without engine deposits were compared, and it was found that a large cooling energy loss contraction occurred in the deposited engine.

Also observed in the present study was that the combustion rate was greater under deposited conditions. These observations strongly suggest that engine deposits have a potentially beneficial effect for controlling fuel consumption.
\end{abstract}

\section{Introduction}

The octane requirement of a gasoline engine increases with deposit buildup in the engine, and this octane requirement increase (ORI) may lead to engine $\operatorname{knock}^{1), 2)}$. The ORI is proportional to the amount of deposits in the same engine ${ }^{3), 4)}$. Nontheless, no clear-cut correlation between ORI and engine deposits has been reported in a statistical study using different engines. We observed that ORI modified by the initial octane requirement was correlative with the carbon concentration of deposits per unit surface area of the combustion chamber of an engine $\mathrm{e}^{\mathbf{1}), 3)}$.

Very recently two papers have mentioned concerning the fuel-saving brought about by engine deposits $^{5), 6)}$. Surprisingly, neither paper described the direct influence of engine deposits on engine efficiency that prompted us to investigate this aspect of the problem. The present study concerns primarily with the combustion analysis under deposited conditions and the effect of engine deposits on fuel economy in a mini-engine.

\section{Experimental}

Mini-engine test: A commercial mini-engine (one cylinder, L-head, 4 cycle, $200 \mathrm{cc}$, compression ratio 6.5) was used for combustion analysis. De-

Received Sept. 3, 1981 .

* Central Research Laboratory, Toa Nenryo Kogyo Co., Ltd.(175, Tsurugaoka, Oi-machi, Iruma-gun, Saitama 354) tails of the engine, operating conditions, and fuel/ lubricant used were described in a previous paper ${ }^{3)}$. The mini-engine was equipped with a knockmeter, thermocouples, a pressure transducer, and a crank angle detector.

The engine torque was controlled by a FRECDynamometer (Meidensya FCDY-7.5 $)^{7}$.

Combustion Analysis: The combustion analytical system used in the present study consisted basically of the mini-engine and a microcomputer (eight bits). A schematic diagram of the system is shown in Fig. 1.

The highest speed of data reading of this system was $50 \mu \mathrm{s}$, and the data read at every one degree of crank angle were converted to digital values through an $\mathrm{A} / \mathrm{D}$ converter to calculate the mean effective pressure, the indicated horse-power and other energy distributions.

ORI and Fuel consumption measurements: For details refer to a previous paper ${ }^{3)}$. The ORI of the mini-engine during 40 hours' operation was intermittently measured using the primary reference fuels of one research octane number increment. Using the combustion analytical system, fuel consumption was determined by direct reading of the meter values of the fuel supply system which was controlled by the dynamometer's torque (held constant).

\section{Results and Discussion}

We have been using a mini-engine to study the ORI problems because of its ease of handling. 


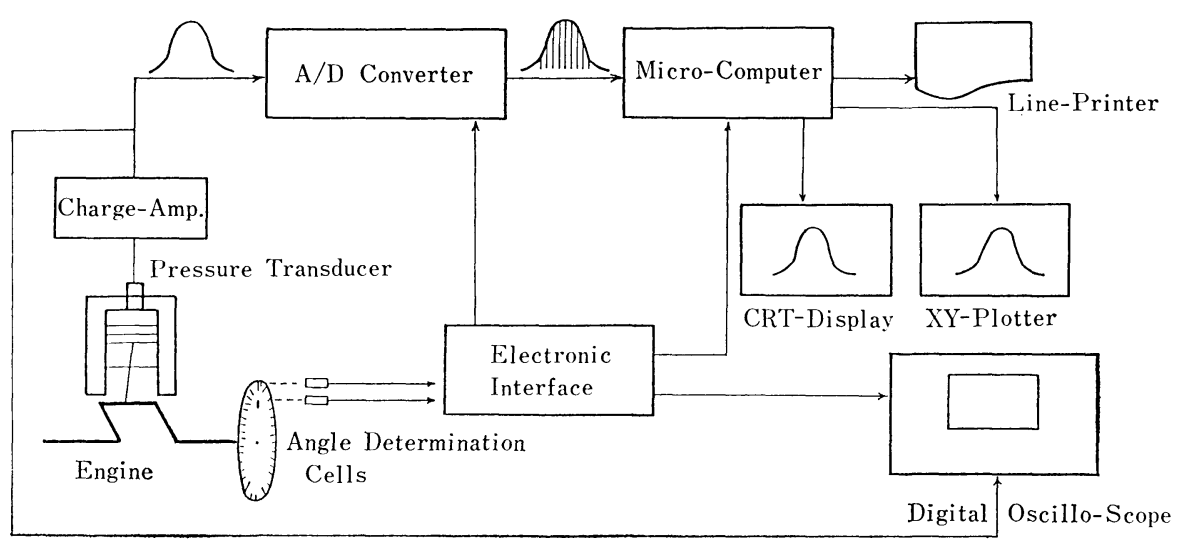

Fig. 1 Scheme of Combustion Analysing System

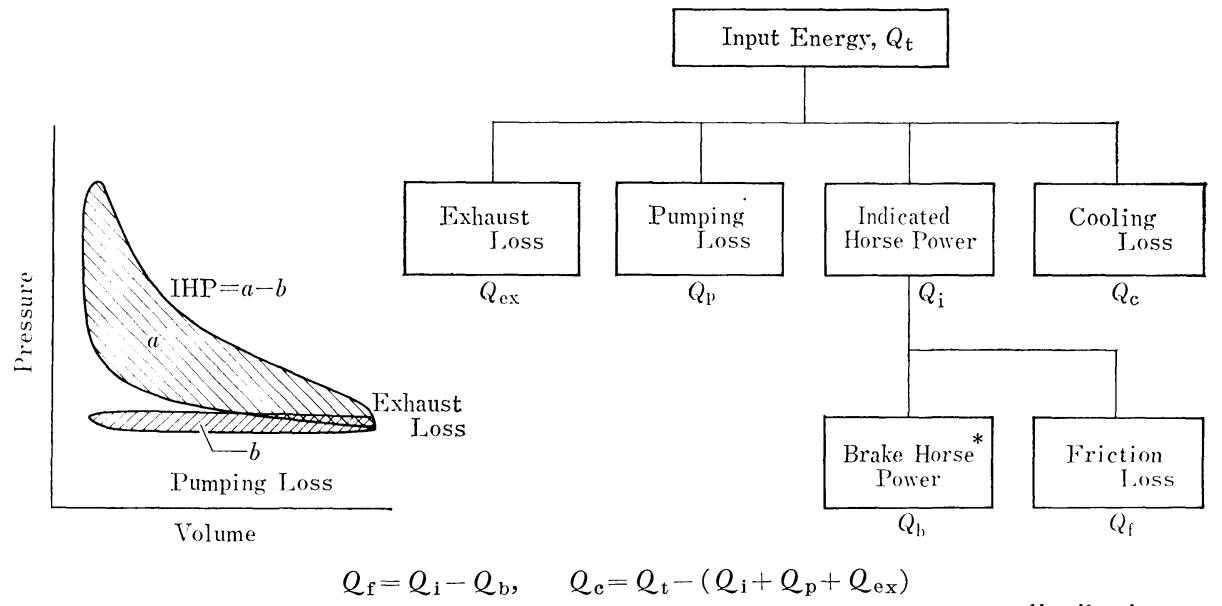

* In the present study, BHP $\left(Q_{\mathrm{b}}\right)$ was kept constant to measure energy distribution.

Fig. 2 Energy Flow in Engine

Using this type of engine, a combustion analytical system was developed to investigate the deposit effects on fuel economy.

The indicator diagram of the 4 cycle internal combustion engine can be schematically as shown in Fig. 2, and the energy flow in the mini-engine employed in the present study is thus given in the right half of the same Figure. We are particular interested in fuel economy under light load (partial throttle) conditions, since the driving patterns of most privately owned cars for personal use involve such part load driving operations ${ }^{8}$.

Under such conditions as those employed in the present study, the energy distribution in the mini-engine was compared with that of the EPA cycle $^{9}$ ) of a water cooled passenger car engine in Table 1, showing a larger energy dissipation due to cooling in the mini-engine.

To investigate the effect of engine deposits on energy distribution in this mini-engine, an accumulation run was carried out, and the combustion
Table 1 Comparison of Energy Distributions

\begin{tabular}{l|cc}
\hline & $\begin{array}{c}\text { Mini-Engine* } \\
(\%)\end{array}$ & $\begin{array}{c}\text { EPA Cycle } \\
(\text { Literature9) } \\
(\%)\end{array}$ \\
\hline Cooling Energy Loss, $Q_{\mathrm{c}}$ & 42 & 29 \\
Exhaust Energy Loss, $Q_{\mathrm{ex}}$ & 31 & 33 \\
Pumping Energy Loss, $Q_{\mathrm{p}}$ & 3 & 6 \\
Indicated Horse Power, $Q_{\mathrm{i}}$ & 24 & 32 \\
Brake Horse Power, $Q_{\mathrm{b}}$ & 16 & 25 \\
Friction Energy Loss, $Q_{\mathrm{f}}$ & 8 & 7.5 \\
\hline
\end{tabular}

* 1,620 rpm, 1/3 of full load

rate was followed with a combustion analyzer, keeping the brake horsepower constant. The oil temperature was kept constant $\left(80^{\circ} \mathrm{C}\right)$ during the deposit accumulation test using an external control system. Octane number requirements and the cylinder head wall temperature were measured intermittently.

The results obtained are summarized in Fig. 3. With a deposit buildup, the fuel charge decreased to result in a fuel saving of ca. $7 \%$ after 40 hours' accumulation. As mentioned in our 


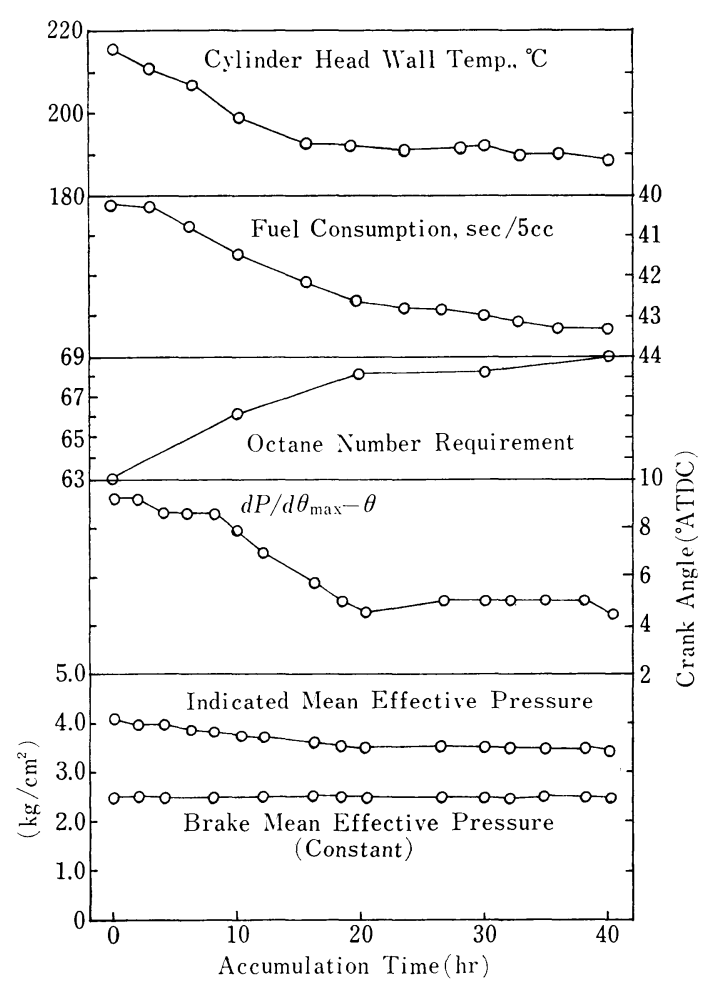

Fig. 3 Effect of Accumulation on Energy Flow, ONR, and Combustion Rate under 1,620 rpm, 1/3 of Full Load Using Unleaded Fuel and Commercial SAE 30 Oil

previous paper ${ }^{3)}$, the octane requirement increase of the mini-engine levelled off after around 20 hours under the conditions employed. The results shown in Fig. 3 appear to be consistent with our former observation ${ }^{3}$. In parallel with the fuel charge decrease, the indicated horsepower decreased, and the combustion rate under deposited conditions increased, as determined by reading the crank angle where the differential of $P-\theta$ curve, $d P / d \theta$, showed a maximum value (Fig. 3).

Bottom photographs in Fig. 4 show the deviations of $P_{\max }$. from the averages plotted at every cycle. The observed smaller fluctuation of $P_{\max }$. in the deposited engine suggests that more homogeneous combustion is occurring under the deposited conditions.

It is interesting to note here that the cylinder head wall temperature also decreased with the deposit buildup as shown in Fig. 3, reflecting thermal insulation properties of the deposits.

In this connection, we reported ca. $8-15 \%$ fuel benefits obtained by using Teflon coated cylinder heads $(0.05 \mathrm{~mm}-0.08 \mathrm{~mm}$ thick $)$ in the mini-engine $^{6)}$.

A comparison of the energy distribution before and after the deposit buildup in the present study is shown in Fig. 5. Decreases in the cooling loss $(4 \mathrm{cal} / \mathrm{cycle})$ and in the friction loss $(1.5 \mathrm{cal} /$ cycle) were observed with the deposited engine, and $c a .7 \%((74.6-69.5) \times 100 / 74.6)$ of fuel benefit was obtained with the deposited engine. The increased combustion rate in the deposited engine suggests that energy dissipation to the exhaust decrease with deposits. The observed exhaust energy loss was, however, $0.4 \mathrm{cal} /$ cycle larger than that of the clean engine. This is possibly due to a large cooling energy loss in the clean engine over the deposited engine (see Fig. 6). The fuel benefit of $c a .7 \%$ obtained in this study was found quite similar to our former results, where the average fuel benefit was $c a .6 \%$ in the ORI range of from 3 to $8 \mathrm{RON}$ observed in 11 commercial passenger cars $^{6}{ }^{\text {. }}$. Since engine displacements, compression ratios, frictional behaviors etc. are different in the above two cases, we feel that these values are not necessarily comparable, and that the observation is suggesting that the fuel benefit is in a similar level under the part-load operating conditions regardless of engine type. The decrease in the friction energy loss in the deposited engine would be due to the decreased heat flow through the piston rings to the cylinder. This would provide more desirable lubrication between the piston rings and the cylinder wall. It is noted that no viscosity decrease in the lubricating oil employed was observed after the test. This aspect of the friction energy loss is, however, still open to question.

Using the basic data of indicator diagram of the mini-engine, a ratio of the cooling energy losses with and without engine deposits, $\left(Q_{\mathrm{cd}}\right)$ $\left.Q_{\mathrm{c}}\right), \quad\left(Q_{\mathrm{c}}\right.$ denotes the cooling energy loss of a clean engine and $Q_{\text {ed }}$ the cooling energy loss of a deposited engine) was approximated in the form of a ratio of the respective overall heat transfer coefficients, and the calculation of $Q_{\text {cd }} / Q_{c}$ resulted in 0.95 to 0.85 depending upon the thickness and thermal conductivity of the deposit layer ${ }^{10}$. Such a cooling loss contraction in the deposit engine will be reflected in the indicated horsepower (IHP) depending upon the change of $Q_{\text {ex }}$ and $Q_{\mathrm{p}}$ (refers to Fig. 2). Under the light load conditions where the brake horsepower was kept constant (Fig. 5), the observed cooling energy loss contraction due to the deposits (4 cal/cycle) was reflected in the decreased input energy $\left(Q_{t}\right)$ (5.1 cal/cycle), and this in turn contributed to the fuel economy improvement.

The fuel-saving benefits observed under the light 

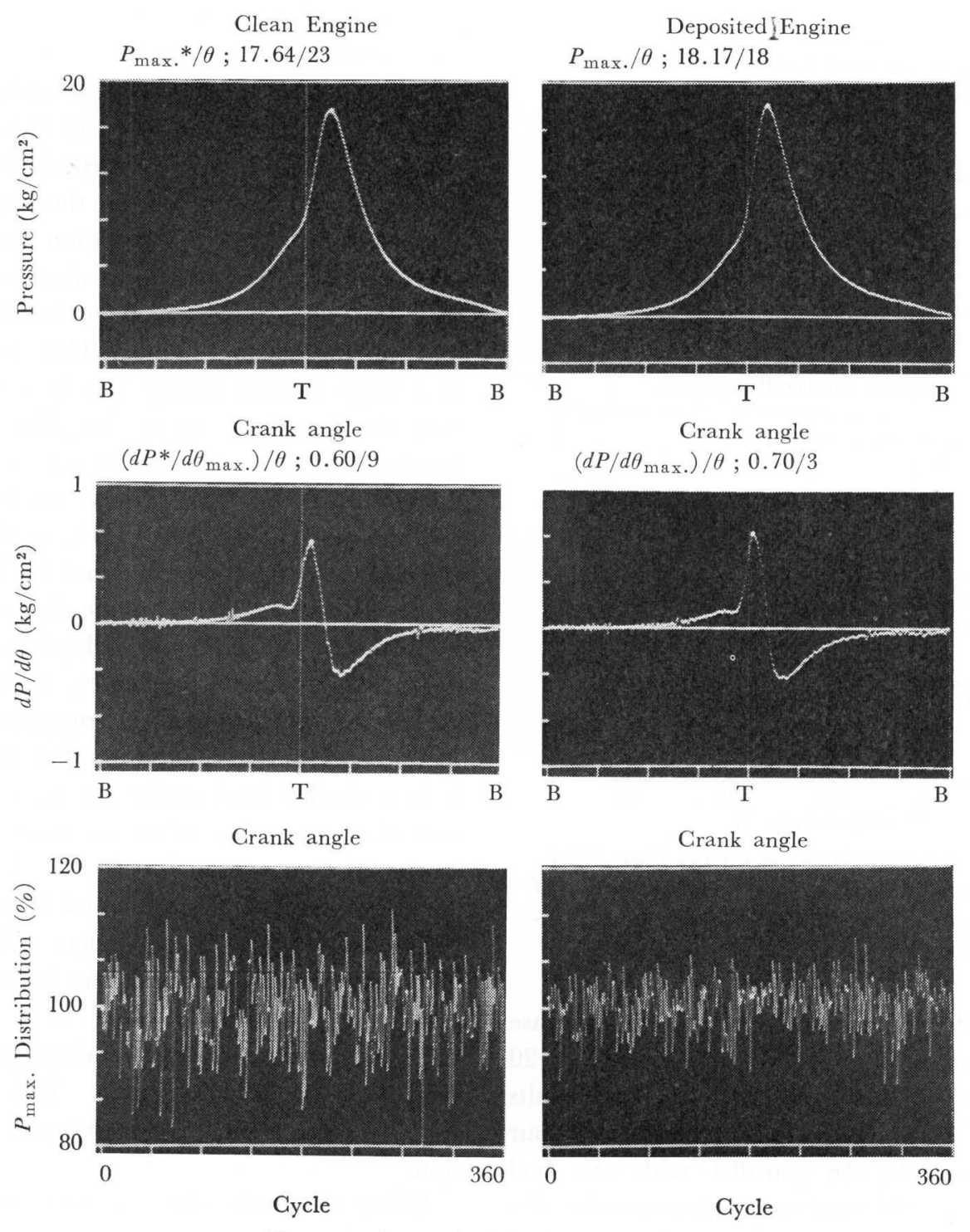

*Pressure $\left(\mathrm{kg} / \mathrm{cm}^{2}\right) / \mathrm{Crank}$ angle $\left({ }^{\circ} \mathrm{ATDC}\right)$

Fig. 4 Comparison of Indicator Diagrams between Clean and Deposited Engines

load conditions in the deposited engine, thus, came mostly from the cooling energy loss contraction due to the thermal insulation effect of the deposits. This effect, however, appeared to be exaggerated, relative to a larger displacement engine, in such a small displacement engine as the one used in the present study. But we still feel that engine deposits do play a potentially important role in controlling fuel consumption through the mechanism mentioned above.

There seem to be two major approaches to controlling fuel consumption: one by engine modification, and the other by decreasing engine deposits. The latter approach, however, has been confined to lessening the deposit buildup in an engine. The present study aimed at finding a possible way to utilize engine deposits.

Unfortunately, we have not yet obtained any beneficial way of using the deposits for controlling fuel consumption, but the results mentioned here may provide a potential use of the deposits for this purpose.

\section{Conclusions}

The engine deposits in a mini-engine were found to afford a beneficial effect on fuel saving. Energy distributions with and without engine deposits were compared and it was found that a large cooling energy loss contraction (ca. 13\%) occurred in the deposited engine.

Also observed in the present study was that the combustion rate was greater under deposited 


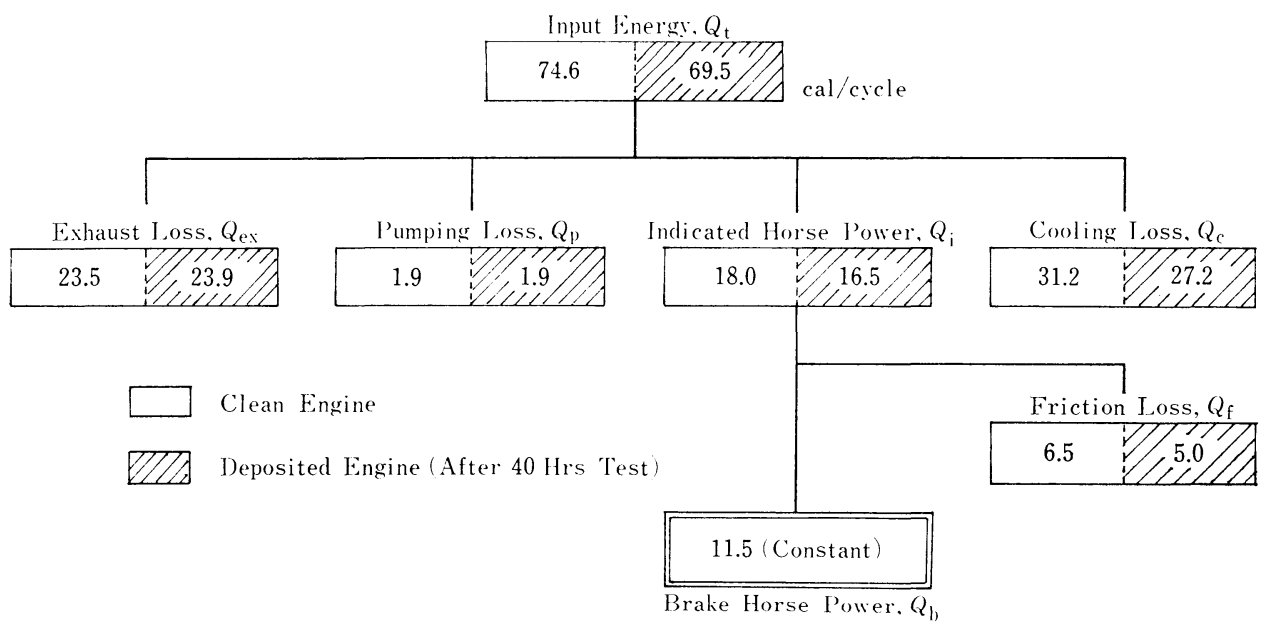

Values shown here were determined under the part load operating conditions $(1,620 \mathrm{rpm}, 1 / 3$ full of load) using unleaded fuel (91 RON) and lubricating oil of SAE 30.

To determine the friction loss, oil temperature was kept constant $\left(80^{\circ} \mathrm{C}\right)$ through the experiments.

Under deposited conditions, ORI of 6 was obtained, and the total deposit weight was 0.91 grams.

Input energy, $Q_{t}$, was calculated based on the data of fuel sp. gr. $0.77\left(20^{\circ} \mathrm{C}\right)$ and $10,500 \mathrm{kcal} / \mathrm{kg}$.

Fig. 5 Comparison of Energy Distributions with and without Combustion Chamber Deposit in MiniEngine

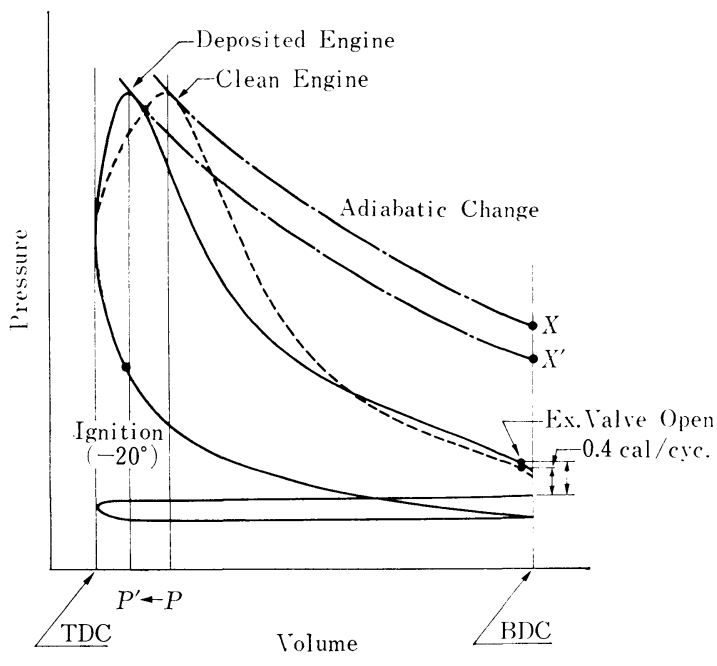

In the deposited engine, the combustion rate increases as denoted by the $P_{\max }$. advancement from $P$ to $P^{\prime}$ which will contract exhaust energy loss from $X$ to $X^{\prime}$ under adiabatic conditions. Observed exhaust energy loss of the deposited engine resulted in $0.4 \mathrm{cal} / \mathrm{cycle}$ larger than that of the clean engine. This is possibly due to larger cooling loss of the clean engine.

Fig. 6 Schematic Indicator Diagram of Clean and Deposited Engine

conditions. These observations strongly suggest that engine deposits could be beneficial for controlling fuel consumption.

\section{Acknowledgement}

The authors greatly appreciate the many useful suggestions of and discussions with Dr. T. Yamaji of Tonen C. R. L. during this work.

\section{References}

1) Nakamura, Y., Yonekawa, Y., Okamoto, N., J. Japan Petrol. Inst, 22, 105 (1977).

2) Mikita, J. J., Sturgis, B. M., Proceedings of the 4th World Petroleum Congress Section V1/F Paper 1. Presented on June 18th (1955).

3) Yonekawa, Y., Nakamura, Y., Okamoto, N., $J$. Japan Petrol. Inst., 24, (2), 85 (1981).

4) Lee, R. C., Tohmas, P., Symposium on Octane in the 1980's Car. Presented at ACS Miami Beach Meeting, Sept. 10-15 (1978), Division of Petroleum Chemistry INC.

5) Graiff, L. B., SAE Paper, 790938 (1977).

6) Nakamura, Y., Yonekawa, Y., Okamoto, N., Symposium on Chemistry of Engine Combustion Deposit Presented at ACS Atlanta Meeting, March 29April 3, (1981), Division of Petroleum Chemistry INC.

7) Suzuki, Y., Kamijo, K., Meiden Jiho 1979 No. 6, (Series No. 149) p. 3.

8) Takano, N., J. Japan Petrol. Inst, 12, (4), 301 (1969).

9) Pinkus, O., Wilcock, D. F., "Strategy for Energy Conservation through Tribology", (1977), ASME.

10) Kokubo, K., Unpublished. 
要 旨

\title{
燃焼室たい積物の研究（第 5 報）
}

\section{燃料経済性に対する燃焼室たい積物の役割り}

\author{
米川喜明*, 小久保確郎*, 中村良信*, 岡本伸和*
}

燃焼解析システムを組み込んだミニエンジン試験により軽負 荷条件での燃焼室たい積物の燃費への影響を検討した（Fig. 1)。エンジンの燃焼解析およびェネルギー分布の測定から，た

* 東亜燃料工業株式会社中央研究所 (354 埼玉県入間郡大井 町鶴ヶ岡 175)
い積物による燃料経済性の向上はたい積物による冷却損失，摩 擦損失の低減 (Figs. 3, 5) と燃焼性の向上 (Fig. 4) によっ ていることがわかった，

これらの結果は燃焼室たい積物がェンジンの燃料消費量を有 利にコントロールする作用をもっていることを示している。

\section{Keywords}

Combustion, Engine deposit, Fuel economy, Knocking, Octane number requirement 